\title{
FORMULASI NANOEMULGEL EKSTRAK KULIT MANGGIS (Garcinia Mangostana L.)
}

\author{
Hilda Damayanti ${ }^{1}$, Saleh Wikarsa ${ }^{2}$, Garnadi Jafar ${ }^{3}$ \\ 1,3 Universitas Bhakti Kencana Bandung \\ ${ }^{2}$ Institut Teknologi Bandung \\ Email Korespondensi : hildadamay99@gmail.com
}

\begin{abstract}
ABSTRAK
Sediaan kosmetik antioksidan berfungsi sebagai antiaging melalui kemampuannya untuk menghambat radikal bebas. Ekstrak kulit buah manggis memiliki aktifitas antioksidan yang sangat kuat. Untuk meningkatkan efektifitas dan kenyamanan penggunaan kulit manggis pada kulit dilakukan formulasi dalam sediaan kosmetik nanoemulgel.Tujuan penelitian ini adalah memformulasikan sediaan nanoemulgel kulit manggis dengan menggunakan bahan-bahan yang halal yang dinyatakan halal sesuai syariat islam. Bahan kosmetik yang digunakan tidak mengandung bahan bangkai, darah, babi dan atau hewan yang tidak sesuai dengan syariat islam. Nanoemulgel kulit manggis dibuat dengan cara memvariasikan konsentrasi Plantacare ${ }^{\circledR} 1200$ UP sebagai kosurfaktan $(5,10,15,20$ dan 25\%) nanoemulsi kemudian diinkorporasikan ke dalam basis gel, setelah itu dilakukan evaluasi. Evaluasi meliputi pengujian aktifitas antioksidan, pengamatan organolpetik, $\mathrm{pH}$, viskositas, uji stabilitas, ukuran partikel serta uji panelis. Aktivitas antioksidan dengan metode DPPH menunjukan nilai $\mathrm{IC}_{50}$ ekstrak kulit manggis yaitu 5,545 ppm yang menunjukan bahwa memiliki aktifitas antioksidan yang sangat kuat. Nanoemulsi pada formula 3 dengan konsentrasi kosurfaktan $15 \%$ memberikan hasil terbaik dengan parameter dapat ditembus sinar laser dengan ukuran partikel 23,65 nm, hasil Tranmission Electron Microscopy (TEM). Nanoemulgel dengan konsentrasi viscolam ${ }^{\circledR}$ MAC 10 tujuh persen menghasilkan formula yang stabil dengan parameter uji freeze thaw dan sentrifuga. Kelima formula menghasilkan sediaan kosmetik nanoemulgel yang stabil.
\end{abstract}

Kata kunci : Kulit Manggis, Nanoemulgel, Antioksidan 


\title{
NANOEMULSION-GEL OF MANGOSTEEN PEEL EXTRACT (Garcinia Mangostana L.)
}

\begin{abstract}
Antioxidant-containing cosmetic has antiaging therapy that can inhibit the free radical formation. Mangosteen peel extract has very strong antioxidant activity. To enhance the effect and comfortness of mangosteen peel extract use on the skin, it could be made into nanoemulgel. The article provides the information about method of preparation and evaluation of nanoemulsion-gel. The purpose of this study was to formulate a stable microemulgel of mangosteen peel extractusing halal materials declared halal according to Islamic Shari'a. the materials used don't contain carrion, blood, pig and/ animals that don't conform to Islamic Shari'a. Microemulgel mangosteen peel extract was made by varying plantacare ${ }^{\circledR} 1200$ UP concentration as cosurfactant $(5,10,15,20$ and 25\%) in the microemulsion and it was incorporated into the gel base. Evaluations were included the antioxidant activity test and organoleptic, $\mathrm{pH}$, viscosity, stability, particle size analysis and panelist test. The antioxidant activity determined by DPPH method showed that IC50 value of mangosteen peel extract was 5.54 ppm. The third microemulsion formula containing cosurfactant of $15 \%$ resulted in the best results in that the parameter of the product can be penetrated by ray laser was at particle size of $23.65 \mathrm{~nm}$, was determined by tranmission Electron Microscopy (TEM). Microemulgel containing Viscolam ${ }^{\circledR}$ MAC 10 of seven percent gave the stable formula proofed by freeze thaw and sentrifuga test. The five microemulgel formulations were stable.
\end{abstract}

Keywords : Mangosteen Peel, Nanoemulgel, Antioxidant

\section{PENDAHULUAN}

Penuaan kulit/ skin aging adalah perubahan dermatologi yang berkembang karena usia seseorang atau karena paparan radiasi ultraviolet (UVR). Penuaan kulit ditandai dengan kulit yang kering, kasar, berpigmen dan melipat/ kerut secara khusus pada wajah dan tangan (faktor ekstrinsik), adanya kerutan yang halus dan lembut, kulit yang kering dan pucat (faktor intrinsik). Dengan paparan sinar matahari, kulit akan mengabsorpsi radiasi UV menghasilkan generasi Reaktive oxygen Species (ROS). Antioksidan bertindak sebagai anti aging (penuaan dini) karena

kemampuannya

mempertahankan homeostatis pada ROS (Reactive Oxidative Species) di dalam sel (Jadoon dkk., 2015).

Menurut penelitian Palakawong dkk tahun 2011, ekstrak kulit manggis memiliki keunggulan bila digunakan dalam sediaan kosmetik karena efeknya dalam regenerasi jaringan, serta memiliki aktivitas antioksidan dan antibakteri. Berdasarkan hasil penelitian aktivitas antioksidan pada kulit manggis yang diperoleh dengan metode peredaman radikal bebas DPPH memiliki nilai $\mathrm{IC}_{50} 5,94 \mu \mathrm{g} / \mathrm{mL}$ aktivitas 
antioksidan yang sangat kuat memiliki nilai $\mathrm{IC}_{50}$ kurang dari $50 \mu \mathrm{g} / \mathrm{mL}$.

Nanoemulgel diformulasi dari nanoemulsi yang diinkorporasi kedalam basis gel. Nano emulsi secara termodinamika stabil dan transparan namun penggunaan pada kulit tidak nyaman dan memiliki viskostas yang rendah sehingga ditambahkan gel untuk meningkatkan kekentalan dan kenyaman (Khurana dkk.,2013)

Indonesia sebagai negara dengan jumlah penduduk muslim Indonesia yang tebesar di dunia yang mempengaruhi dalam pembelian kosmetik berlabel halal (Hardiati, 2016). Berdasarkan Undang-undang Republik Indonesia (UU RI No. 33 tahun 2014) produk halal adalah produk yang dinyatakan halal sesuai syariat islam. Bahan kosmetik yang digunakan tidak mengandung bahan yang berasal dari hewan yang diharamkan dalam pasal 18 bahan tersebut yaitu bangkai, darah dan babi dan atau hewan yang tidak sesuai dengan syariat islam.

Untuk meningkatkan efektifitas dan jaminan halal dapat dilakukan formulasi nanoemulgel ekstrak kulit manggis. Emulgel adalah emulsi, baik itu air dalam minyak ataupun minyak dalam air yang dibuat sediaan gel dengan mencampurkan gelling agent (Baibhav dkk, 2012). Nanoemugel dibuat dengan cara nanoemulsi diinkorporasi ke dalam basis gel.

Berdasarkan latar belakang masalah diatas maka dirumuskan masalah sebagai berikut Bahan-bahan apa saja yang digunakan untuk mendapatkan sediaan kosmetik nanoemulgel yang halal dan Bagaimana cara preparasi dan evaluasi sediaan kosmetik nanoemulgel ekstrak kulit manggis. Tujuan penelitian ini adalah mendapatkan formulasi sediaan nanoemulgel yang stabil dari ekstrak kulit manggis yang memiliki aktivitas antioksidan

\section{METODE PENELITIAN MATERIAL}

Ekstrak kulit manggis, etanol $96 \%$, tween 80 , plantacare ${ }^{\circledR} 1200 \mathrm{UP}$, minyak zaitun, viscolam ${ }^{\circledR}$ MAC 10 , propilenglikol, gliserin, DMDM hydantoin dan aquadest

\section{Rancangan Penelitian}

Formula nanoemulsi dibuat dengan mencampurkan Tween 80 dan Minyak zaitun kemudian ditambahkan larutan plantacare ${ }^{\circledR} 1200$ UP selanjutnya ditambahkan fase air setelah itu diaduk dengan menggunakan magneticheater stirrer pada kecepatan 500 rpm selama 5 menit. Ekstrak kulit manggis kemudian ditambahkan terakhir pada campuran tersebut.

Tabel 1 Formulasi Nanoemulsi Ekstrak kulit manggis

\begin{tabular}{|l|l|l|l|l|l|}
\hline $\begin{array}{l}\text { Plantacare }^{(1200} \\
\text { UP }\end{array}$ & 5 & 10 & 15 & 20 & 25 \\
\hline Minyak Zaitun & 3 & 3 & 3 & 3 & 3 \\
\hline DMDM Hydantoin & 0,6 & 0,6 & 0,6 & 0,6 & 0,6 \\
\hline Aquadest add & 100 & 100 & 100 & 100 & 100 \\
\hline
\end{tabular}




\section{Pengamatan Morfologi}

Morfologi nanoemulsi kulit manggis dianalisis menggunakan transmission electron microscopy (TEM). $10 \mu \mathrm{L}$ nanoemulsi diteteskan di atas spesimen. Alat grid 400 mesh diletakan diatas spesimen yang sudah terdapat tetesan nanoemulsi dan dibiarkan selama 1 menit. Sisa tetesan nanoemulsi pada grid dibersihkan menggunakan kertas saring kemudian diteteskan $10 \mu \mathrm{L}$ uranil asetat diatas grid dan sisa tetesan dibersihkan kembali menggunakan kertas saring. Grid dibiarkan selama 30 menit hingga kering dan dimasukan kealat TEM untuk diambil gambarnya

\section{Pembuatan nanoemulgel ekstrak kulit manggis}

Kelima nanoemulsi ekstrak kulit manggis yang terbentuk diinkorporasikan kedalam gel viscolam ${ }^{\circledR}$ MAC $\quad 10 \quad$ dengan menggunakan ultra turax selama 10 menit hingga terbentuk nanoemulgel yang homogen.

\section{Pengamatan Organoleptik}

Pengamatan organoleptik dilakukan dengan mengamati perubahan konsistensi warna, bau nanoemulgel ekstrak kulit manggis dengan berbagai konsentrasi.

\section{Pengukuran pH}

Pengukuran $\mathrm{pH}$ dilakukan dengan menggunakan $\mathrm{pH}$ meter, dimana bagian katoda pada $\mathrm{pH}$ meter dicelupkan kedalam nanoemulgel, dan selanjutnya dilihat nilai $\mathrm{pH}$ yang terukur pada layar hingga diperoleh angka yang stabil.Pengamatan dilakukan pada sediaan yang baru dibuat dan telah mengalami penyimpanan.

\section{Pengukuran Viskositas}

Pengukuran viskositas dilakukan dengan menggunakan viskotester, dengan cara memasukan spindel yang sesuai (spindel 64) kedalam wadah yang berisi nanoemulgel hingga tanda batas. Klep pengamanan dilepaskan dan rotor dinyalakan sampai diperoleh angka viskositas.

\section{Pengujian Sentrifugasi}

Nanoemulgel ditimbang sebanyak 1 gram dan dimasukan kedalam tabung sentrifugasi. Kemudian nanoemulgel ditisentrifugasi pada suhu ruangan dengan kecepatan 3800 rpm selama 5 jam.

\section{Pengujian Freez Thaw}

Uji "freeze thaw" dilakukan dengan menganalisa formula yang disimpan pada suhu rendah $\left(4^{\circ} \mathrm{C}\right)$ selama 48 jam lalu dikeluarkan dan ditempatkan pada suhu tinggi $\left(40^{\circ} \mathrm{C}\right)$ selama 48 jam. Perlakuan ini adalah satu siklus. Percobaan di ulang selama 6 siklus. Kondisi fisik sediaan di bandingkan selama percobaan dengan sediaan sebelumnya untuk menganalisa terjadinya kristalisasi atau tidak

\section{Pengujian Kualitatif Aktivitas Antioksidan dengan Kromatografi Lapis tipis}

Ekstrak dan sediaan nanoemulgel kulit buah manggis diuji 
sifat antioksidan yang terlebih dahulu dilakukan pemisahan secara Kromatografi Lapis Tipis dengan fase diam silika gel dan fase gerak n-heksan: etil asetat (7:3) dan butanol: asam asetat : air (4:1:5). Hasil elusi kemudian dikeringkan dan disemprot dengan penampak bercak DPPH.

\section{Pengujian Kuantitatif Aktivitas Antioksidan dengan spektrofotometer UV-Vis}

Larutan uji ekstrak kulit manggis dibuat konsentrasi 20 microgram $/ \mathrm{mL}$ dalam pelarut metanol. Pengujian dilakukan dengan cara penambahan $3 \mathrm{~mL}$ larutan sampel dengan kadar tertentu dengan 2 $\mathrm{mL}$ larutan DPPH microgram $/ \mathrm{mL}$. Campuran selanjutnya dihomogenkan dan diukur serapannya setelah 30 menit pada spektrofotometer dengan panjang gelombang $516 \quad n m . S e b a g a i$ pembanding digunakan vitamin $\mathrm{C}$

\section{Besarnya presentase pengikatan radikal bebas dihitung dengan rumus: (\% inhibisi)}

Ket :

\section{A kontrol : Absorbansi DPPH \\ $\mathrm{A}_{\text {sampel }}$ : Absorbansi DPPH setelah penambahan sampel}

\section{HASIL DAN PEMBAHASAN}

Untuk mendapatkan formulasi nanoemulsi yang stabil terlebih dahulu dilakukan percobaan pendahuluan. Tahap ini dilakukan dengan cara mencampurkan fasa air, fasa minyak, surfaktan dan kosurfaktan serta melakukan variasi parameter proses.

Hasil percobaan pendahuluan didapat kondisi optimum untuk membuat nanoemulsi yaitu dengan kecepatan stirrer $500 \mathrm{rpm}$ selama 5 menit.Pembuatan nanoemulsi terlebih dahulu dilakukan orientasi konsentrasi surfaktan. Hasil menunjukan bahwa pada konsentrasi 25 dan $30 \%$ belum memberikan nanoemulsi yang stabil, tetapi pada konsentrasi $35 \%$ sudah dapat menghasilkan nanoemulsi yang stabil.

\section{Pengamatan Ukuran Partikel} Tranmission electron microscopy (TEM) digunakan untuk menguji morfologi nanopartikel dan konfirmasi ukuran partikel yang dihasilkan dari pengukuran distribusi ukuran partikel. Formula 3 merupakan formula yang mampu dilewati sinar laser terbaik yang selanjutnya diuji ukuran partikel. Hasil tranmission electron microscopy (TEM) ukuran globul nanoemulsi ekstrak kulit manggis pada formula 3 yaitu 23,65 nm (Gambar 1). Ukuran partikel atau droplet menjadi karakteristik kimia yang penting pada nano emulsi. 
keuntungannya yaitu dapat meningkatkan kelarutan, meningkatkan pelepasan obat dan dapat meningkatkan bioavaibilitas (Mahdi dkk., 2011). Semakin kecil ukuran partikel dapat meningkatkan luas area yang dapat meningkatkan penetrasi kulit (Harwansh dkk., 2015). ukuran partikel yang kecil dapat mencegah pemisahan dan flokulasi (woostek dkk.m 2008).

\begin{abstract}
Nano emulgel merupakan sistem penghantaran yang dapat meningkatkan aktifitas antioksidan yang berkhasiat sebagai antiaging. Nanocarrier seperti nano emulgel yang memiliki ukuran partikel atau droplet $<500 \quad \mathrm{~nm}$ diaplikasikan pada permukaan kulit untuk memberikan efek lokal pada kulit, dermal ataupun transdermal (Montenegro, 2014).
\end{abstract}

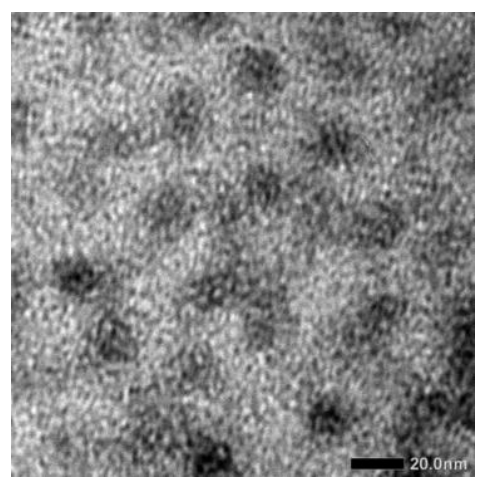

Gambar 1: Hasil pengukuran ukuran partikel dengantranmission electron microscopy

(TEM) perbesaran $150.000 \mathrm{x}$

Nanoemulgel ekstrak kulit manggis diformulasikan dengan mengiinkorporasi kelima nanoemulsi kedalam basis gel, hasil optimasi basis gel sebelumnya yaitu viscolam ${ }^{\circledR}$ MAC $105 \%$ tidak dapat membentuk nanoemulgel sehingga konsentrasi viscolam $^{\circledR}$ MAC 10 ditingkatkan, sehingga pada konsentrasi $7 \%$ nanoemulgel terbentuk. Kemudian dilakukan uji evaluasi meliputi uji organoleptis, $\mathrm{pH}$, viskositas, freeze thaw, sentrifuga dan uji aktifitas antioksidan secara kualitatif

Tabel 2 Pengukuran pH Nanoemulgel ekstrak kulit manggis

\begin{tabular}{|l|l|l|l|l|l|l|}
\hline \multirow{2}{*}{$\begin{array}{l}\text { Nano- } \\
\text { Emulgel }\end{array}$} & \multicolumn{6}{|l|}{ Pengukuran pH Hari ke- } \\
\cline { 2 - 7 } & 1 & 3 & 7 & 14 & 21 & 28 \\
\hline F1 & 6,99 & 6,71 & 6,99 & 6,93 & 6,88 & 6,72 \\
\hline F2 & 7,12 & 6,98 & 6,95 & 6,96 & 6,73 & 6,72 \\
\hline F3 & 6,99 & 6,97 & 6,95 & 6,93 & 6,80 & 6,74 \\
\hline F4 & 7,01 & 6,83 & 6,84 & 6,83 & 6,69 & 6,63 \\
\hline F5 & 6,87 & 6,94 & 6,85 & 6,84 & 6,69 & 6,63 \\
\hline
\end{tabular}


Tabel 3 Pengukuran Viskositas Nanoemulgel ekstrak kulit manggis

\begin{tabular}{|l|l|l|l|l|l|l|}
\hline \multirow{2}{*}{$\begin{array}{l}\text { Nano } \\
\text { Emulgel }\end{array}$} & \multicolumn{6}{|l|}{ Pengukuran Viskosita Hari ke- (CPs) } \\
\cline { 2 - 7 } & 1 & 3 & 7 & 14 & 21 & 28 \\
\hline F1 & 68500 & 69000 & 70000 & 70500 & 73000 & 79000 \\
\hline F2 & 67000 & 67500 & 68000 & 68500 & 69000 & 71000 \\
\hline F3 & 54000 & 54500 & 54750 & 55000 & 56500 & 60000 \\
\hline F4 & 36000 & 37000 & 39000 & 44500 & 48000 & 50000 \\
\hline F5 & 34500 & 35000 & 35500 & 36000 & 37000 & 39000 \\
\hline
\end{tabular}

\section{Evaluasi Nanoemulgel}

\section{Pengamatan Organoleptik}

Nanoemulgel berwarna coklat, kental, homogen.Hasil pengamatan nanoemulgel tidak menunjukan perubahan warna dan bau selama 28 hari penyimpanan.

\section{Pengukuran pH}

Nanoemulgel diukur pada hari ke-1, 3, 7, 14, 21 dan 28. Pengukuran dilakukan pada nanoemulgel yang disimpan pada suhu kamar $\left( \pm 28^{\circ} \mathrm{C}\right)$.Nilai $\mathrm{pH}$ menunjukan tidak menunjukan perubahan $\mathrm{pH}$ yang signifikan selama penyimpanan 28 hari. Formula terbaik yaitu formula 3 ditunjukan dengan standar deviasi terkecil (Tabel 2).

\section{Pengukuran Viskositas}

Sediaan nanoemulgel diukur viskositasnya dengan menggunakan viskometer brookfield dengan spindel no 64 pada suhu kamar. Pada pengujian viskositas dari variasi konsentrasi

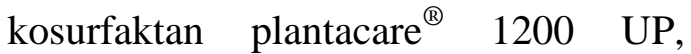
semakin tinggi konsentrasi plantacare ${ }^{\circledR}$ maka semakin menurun viskositasnya (Tabel 3).

\section{Pengujian Freeze Thaw}

Pengujian freez thaw dilakukan untuk mengetahui kestabilan selama 6 siklus dengan penyimpanan suhu yang berbeda. Uji ini dilakukan dengan menyimpan mikro emulgel pada suhu dingin $\left(4^{\circ} \mathrm{C}\right)$ selama 48 jam dan pada suhu panas $\left(44^{\circ} \mathrm{C}\right)$ selama 48 jam percobaan itu diulang selama 6 siklus. Setelah 6 siklus, nanoemulgel tetap stabil tidak mengalami pemisahan fase .

\section{Pengujian Aktivitas Antioksidan} Ekstrak Kulit Manggis

Radikal Bebas dapat menyebabkan kerusakan dan penurunan relatif antioksidan enzimatik dan nonenzimatik yang merupakan sistem pertahanan kulit dan akhirnya dapat menyebabkan berbagai gangguan seperti kanker kulit, menekan sistem kekebalan tubuh termasuk penuaan kulit dini (Chen dkk., 2012). Terapi antioksidan merupakan pengobatan untuk mencegah atau mengurangi efek 
buruk oksidan. Manfaat antioksidan telah di uji sistem in vitro maupun in vivo. Sebagian besar antioksidan, bila diterapkan secara langsung dan pada konsentrasi yang relatif tinggi terhadap sistem seluler secara in vitro efektif memberikan perlindungan melawan oksidan (Suntres, 2011).

Aplikasi antoksidan secara topikal dapat melawan stres oksidatif dan melindungi kulit dari fotoaging. Pendekatan yang paling umum untuk mengamati aktivitas antioksidan yatu dengan pengujian secara in vitro. Sampel dicampur dengan radikal yang stabil kemudian laju degradasi radikal diukur misalkan dengan spektrofotometri. (Zillich et al, 2015).

\section{Uji Kualitatif}

Uji kualitatif dilakukan untuk mengetahui apakah ektrak dan sediaan mikroemulgel kulit buah manggis memiliki sifat antioksidan. Hasil pada plat KLT menunjukan adanya warna kuning hasil penotolan sampel yang disemprot dengan penampak bercak DPPH. Sehingga dapat disimpulkan bahwa sampel ekstrak dan sediaan mikroemulgel ekstrak kulit manggis mengandung antioksidan (Gambar 2).

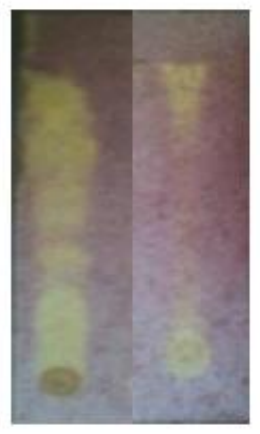

\section{(a) (b)}

Gambar2 : Hasil kromatografi lapis tipis fase diam silica gel $\mathrm{GF}_{254}$

(a) Ekstrak kulit manggis, fase gerak N-heksan : Etil Asetat (7:3)

(b) Sediaan mikroemulgel ekstrak kulit manggis, fase gerak Butanol - Acid Acetat Water (4:1:5)

\section{Uji Kuantitatif DPPH}

Berdasarkan hasil analisis aktivitas penangkal radikal bebas DPPH ekstrak kulit manggis memiliki nilai \% inhibisi terendah yaitu $38,939 \%$ sehingga di dapat nilai $\mathrm{IC}_{50}$ yaitu 5,545 microgram/mL sedangkan pembanding yaitu vitamin $\mathrm{C}$ memiliki didapat nilai $\mathrm{IC}_{50}$ yaitu 5,526 microgram/mL, keduanya memiliki aktifitas antioksidan yang sangat kuat menunjukan nilai $\mathrm{IC}_{50}<50$ microgram/mL. Nilai $\mathrm{IC}_{50}$ dihitung dengan menggunakan rumus persamaan regresi linear $\mathrm{y}=\mathrm{ax} \pm \mathrm{b}$ (Gambar 3). 


\begin{tabular}{|l|l|l|l|l|l|l|}
\hline \multicolumn{1}{|c|}{ Sampel } & \multicolumn{5}{c|}{ VitaminC } & \multicolumn{1}{c|}{ Persamaan } \\
\hline $\begin{array}{l}\text { Konsentrasi } \\
\text { (microgram/mL) }\end{array}$ & 2 & 3 & 4 & 5 & 6 & $\mathrm{Y}=8,47 \mathrm{x}+3,1963$ \\
& & & & & & $\mathrm{r}^{2}=0,997$ \\
\hline \% inhibisi & 21,16 & 27,21 & 37,53 & 44,96 & 54,28 & $\begin{array}{l}\mathrm{IC}_{50}= \\
5,526 \text { microgram } / \mathrm{mL}\end{array}$ \\
\hline $\begin{array}{l}\text { Sampel } \\
\text { (microgram/mL) }\end{array}$ & 1 & 2 & 4 & 8 & 16 & Yersamaan \\
\hline \% inhibisi & 38,939 & 40,880 & 46,054 & 56,015 & 76,326 & $\mathrm{IC}_{50}=$ \\
& & & & & 5,545 microgram $/ \mathrm{mL}$ \\
\hline
\end{tabular}

Kulit manggis merupakan antioksidan yang potensial. Kulit manggis kaya akan derivate a-mangostin dan xanton (yu dkk., 2007). Kulit manggis memiliki $\mathrm{IC}_{50}$ yang hampir setara dengan pembandingnya yaitu Vitamin $\mathrm{C}$ sehingga pada sediaan Nano emulgel konsentrasi ekstrak kulit manggis yang digunakan yaitu sebesar 5\% yang berdasarkan hasil penelitian Humbert dkk. tahun 2003 Vitamin C yang digunakan pada sediaan topikal untuk terapi photoaging adalah 5\% dan penelitian yang dilakukan oleh Raschke, T. dkk. tahun 2004 konsentrasi 3\% asam askorbat dalam kosmetik dapat melawan stress oksidatif.

Topikal antioksidan memiliki banyak manfaat namun tidak dapat bertahan lama di kulit sehingga tidak bisa melindungi kulit darai paparan sinar matahari secaraa maksimal sehingga harus digunakan berulang kali (N.R. Prasad dkk., 2007). Nano emulsi gel merupakan sediaan sustained release yang dapat melawan paparan Sinar
UVA. Nano emulsi gel merupakan suatu sediaan yang stabil, aman dan efektif untuk aplikasi topikal melawan paparan sinar UV (Harwansh dkk., 2015).

\section{SIMPULAN}

Kesimpulan dari penelitian ini adalah pengujian aktivitas atioksidan dilakukan dengan metode DPPH (Diphenylhydrazylpicryl) menunjukan nilai $\mathrm{IC}_{50}$ Ektsrak kulit manggis menunjukan aktifitas antioksidan yang sangat kuat yaitu 5,545 microgram/mL dan pembandingnya Vitamin $\mathrm{C}$ yaitu 5,526 microgram/mL. Hasil Tranmission Electron Microscopy (TEM) ukuran globul nanoemulsi kulit manggis pada formula 3 yaitu 23,65 nm. Berdasarkan data yang diperoleh maka dapat disimpulkan bahwa formulasi nanoemulgel ektrak kulit manggis (ekstrak kulit manggis 3\%, tween 80 $35 \%$, plantacare ${ }^{\circledR} 1200$ UP 5, 10, 15, 20 dan $25 \%$, minyak zaitun 3\%, DMDM Hydantoin 0,6\%, viscolam ${ }^{\circledR}$ MAC 10 $7 \%$, propilen glikol $15 \%$, gliserin $5 \%$, 
trietanolamin 1\%, Aquadest) relatif stabil dengan parameter uji kestabilan meliputi uji freeze thaw dan sentrifuga serta uji pada suhu ruang selama penyimpanan 28 hari dengan parameter $\mathrm{pH}$ dan viskositas.

\section{UCAPAN TERIMA KASIH}

Pada kesempatan ini, peneliti ingin mengucapkan terima kasih kepada berbagai pihak yang telah membantu terwujudnya penelitian ini :

1. Sekolah Tinggi Farmasi Bandung

2. Sekolah Farmasi Institut

Teknologi Bandung

\section{DAFTAR PUSTAKA}

Baibhav, Joshi, S.Gurpreet, Rana A.C. dan S.Seema. (2012).

Development And

Characterization Of

Clarithromycin Emulgel For Topical Delivery.

International Journal of Drug

Development \& Research: 4(3) :310-323

Chen L, Hu JY, Wang SQ. (2012). The

Role Antioxidant in

Photoprotection: a critical review. J Am Acad Dermatol; 43: 112-7.

Hardiati Endah, Nur. (2016). Perilaku Pembelian kosmetik berlabel halal oleh konsumen Indonesia. Jurnal Ekonomi dan Pembagunan 12(1) : 25 - 39

Harwansh, R. K., Mukherjee, P. K., Bahadur, S., \& Biswas, R. (2015). Enhanced permeability of ferulic acid loaded nanoemulsion based gel through skin against UVA mediated oxidative stress. Life Sciences, 141, 202-211. doi:10.1016/j.lfs.2015.10.001

Humbert, P. G., Haftek, M., Creidi, P., Lapiere, C., Nusgens, B., Richard, A., ... Zahouani, H. (2003). Topical ascorbic acid on photoaged skin. Clinical, topographical and ultrastructural evaluation: double-blind study vs. placebo. Experimental Dermatology, 12(3), 237-244.

Jadoon dkk., (2015). Anti-Aging Potential of Phytoextract Loaded-Pharmaceutical

Creams for Human Skin Cell Longetivity Review Article. Hindawi Publishing Corporation idative Medicine and Cellular Longevity

Mahdi, E. S., Sakeena, M. H. F., Abdulkarim, M., Sattar, M., Noor, A. M., \& Abdullah, G. (2011). Formulation and in vitro release evaluation of newly synthesized palm kernel oil esters-based nanoemulsion delivery system for $30 \%$ ethanolic dried extract derived from local Phyllanthus urinaria for skin antiaging. International Journal of Nanomedicine, 2499.

Montenegro, L. (2014). Nanocarriers for skin delivery of cosmetic antioxidants. Journal of Pharmacy \& Pharmacognosy Research, 2(4), 73-92.

N.R. Prasad, S. Ramachandran, K.V. Pugalendi, V.P. Menon. (2007) 
Ferulic acid inhibits UV-B induced oxidative stress in human lymphocytes, Nutr. Res. 27, 559-564

Palakawong, C., Sophanodora, P., Pisuchpen, S. dan Phongpaichit, S. (2010). Antioxidant and antimicrobial activities of crude extracts from mangosteen (Garcinia mangostana L.) parts and some essential oils.International Food Research Journal 17: 583-589

Raschke, T., Koop, U., Düsing, H.-J., Filbry, A., Sauermann, K., Jaspers, S., ... Wittern, K.-P. (2004). Topical Activity of Ascorbic Acid: From in vitro Optimization to in vivo Efficacy. Skin Pharmacology and Physiology, 17(4), 200206.

S. Khurana, N.K. Jain, P.M.S. Bedi. (2013).Nanoemulsion based gel for transdermal delivery of meloxicam: Physicochemical,mechanistic investigation. Life Sciences 92 : 383-392

Suntres, Z. E. (2011). Liposomal antioxidants for protection against oxidant-induced damage. Journal of toxicology, 2011.

Undang undang Republik Indonesia (UU RI) No.33 tahun 2014 tentang jaminaN produk halal

Winarsi, Hery. 2007. Antioksidan Alami dan Radikal Bebas. Yogyakarta: Kanisius
Wooster TJ, Golding M, Sanguansri P. (2008). Impact of oil type on nanoemulsion formation and Ostwald ripening stability. Langmuir.;24(22):1275812765.

Yu, L., Zhao, M., Yang, B., Zhao, Q., Jiang, Y., (2007). Phenolics from hull of Garcinia mangostana fruit and their antioxidant activities. Food Chemistry 104 (1), 176-181. Zillich, O. V., Schweiggert- Weisz, U., Eisner, P., \& Kerscher, M. (2015). Polyphenols as active ingredients for cosmetic products. International journal of cosmetic science, 37(5), 455-464 